\title{
MOTIVASI ENTREPRENEURSHIP PADA MAHASISWA JURUSAN MANAJEMEN PENDIDIKAN
}

\author{
Desi Rahmawati \\ e-mail: desi_rahmawati86@yahoo.com \\ Manajemen Pendidikan, FIP Universitas Negeri Jakarta
}

\begin{abstract}
Abstrak: Penelitian ini bertujuan untuk mengetahui seberapa kuat motivasi entrepreneurship dalam diri Mahasiswa Jurusan Manajemen Pendidikan FIP UNJ. Penelitian ini dilaksanakan dari bulan Mei sampai dengan November 2012. Metode yang digunakan metode deskriptif dan metode eksploratif. Pengumpulan data dilakukan dengan angket dan intervieu/wawancara. Hasil penelitian dapat mendeskripsikan minat mahasiswa jurusan Manajemen Pendidikan untuk berwirausaha, permasalahan dalam mewujudkan suatu usaha, dan hasil evaluasi mahasiswa atas mata kuliah Kewirausahaan.
\end{abstract}

Kata kunci: Motivasi, Kewirausahaan, kecakapan hidup

\section{ENTREPRENEURSHIP MOTIVATION OF EDUCATION MANAGEMENT DEPARTMENT STUDENTS}

\begin{abstract}
The purpose of this study is to discover the motivation strength of the students of Education Management students at The School of Education, State University of Jakarta. Employing descriptive and explanative method, the study was conducted as from May through November 2012. The data were collected using questionaire and interview techniqes. As the result of the study, the students' interest, the problems in developing a business, and the students' evaluation of Entrepreneurship course were presented descriptively.
\end{abstract}

Keywods: motivation, entrepreneurship, life skill

\section{PENDAHULUAN}

\section{Latar Belakang}

Kemajuan suatu bangsa sangat tergantung pada perkembangan kewirausahaan di negara tersebut, karena kewirausahaan adalah faktor kunci keberhasilan perekonomian suatu negara. Mendidik masyarakat berwirausaha sama dengan mencegah masyarakat menjadi pengangguran yang pada akhirnya akan mengurangi kemiskinan. Berkurangnya kemiskinan akan membawa suatu negara pada kemakmuran, karena rumusan suatu negara makmur, yaitu apabila $2 \%$ jumlah penduduknya adalah pengusaha/ wirausaha. Pada tahun 2009, jumlah wirausaha di Indonesia sebanyak 450.000 orang, atau sekitar 0,18\% dari total penduduk Indonesia sebesar 250 juta. Jelas terlihat, bahwa Indonesia belum termasuk negara yang makmur, jika dibandingkan Amerika dengan jumlah wirausaha sebesar 7,2\%, sedangkan Jepang dan Korea $5 \%$. Kondisi di Indonesia cukup lumayan karena data jumlah wirausaha Indonesia pada tahun 2012, meningkat menjadi 1,55 \% dari total jumlah penduduk (http://pendekarinternetmarketing.com/pendidikanwirausaha-dan-kewirausahaan-di-sekolah).
Peningkatan jumlah wirausaha di Indonesia memang cukup pesat dalam sepuluh tahun terakhir ini. Era reformasi yang diikuti dengan kebijakan desentralisasi pada tahun 2000, berdampak sangat signifikan terhadap jumlah wirausaha Indonesia yang akhirnya juga berdampak pada pertumbuhan ekonomi Indonesia yang saat ini berada pada sekitar $6 \%$. Pertumbuhan ekonomi Indonesia tetap menyisakan masalah pengangguran yang hingga kini jumlahnya masih cukup besar. Dari tahun ke tahun perguruan tinggi meluluskan jutaan mahasiswanya, tetapi persoalannya hanya sebagian kecil saja yang terserap di dunia kerja, sebagian lagi masih menganggur atau tidak produktif secara ekonomi.

Selama ini perguruan tinggi sebagian besar hanya memberikan teori tentang pendidikan kewirausahaan dibanding dengan memperbanyak praktiknya. Akibatnya persentase aplikasi atau penerapan ilmu praktik di dunia usaha masih sangat minim. Minimnya pengetahuan membuat mereka kurang siap mengaplikasikan ilmunya dalam praktik kehidupan nyata, sehingga perlu ditanamkan kemampuan berwirausaha, baik secara teori maupun praktik agar mereka dapat mengaplikasikan ilmunya secara tepat. 
Membangun kemampuan wirausaha pada mahasiswa melalui pemberian mata kuliah Pendidikan Kewirausahaan tidak dapat sepenuhnya menjadikan mereka mejadi seorang wirausaha yang sukses. Wirausaha sukses juga sangat ditentukan oleh motivasi kuat dari mahasiswa yang bersangkutan. Pada umumnya, masalah yang dihadapi perguruan tinggi untuk dapat menjadi wadah dalam menghasilkan wirausaha-wirausaha baru tidak mudah mengingat kegiatan utama kampus yaitu mengajar dan mentransfer ilmu-ilmu yang telah ada kepada mahasiswa, sehingga tidak mungkin perguruan tinggi dapat menjadi wadah atau organisasi untuk menghasilkan wirausaha-wirausaha yang inovatif. Agar suatu perguruan tinggi menjadi penghasil wirausaha-wirausaha, maka harus mengubah visi dan misinya, yaitu bukan hanya sebatas sebagai "Learning Institution" atau "Research University", akan tetapi melangkah lebih maju, bagaimana menerapkan hasil pendidikan/pengajaran dan penelitian untuk kepentingan dunia usaha atau menjadi "Entrepreneurial University".

Dalam mendukung lahirnya wirausaha-wirausaha unggulan dari kampus, maka metode perkuliahan kewirausahaan dititikberatkan untuk memotivasi agar mahasiswa mau memilih kewirausahaan sebagai karier hidupnya, di samping untuk memahami disiplin ilmu kewirausahaan. Perkuliahan harus dirancang sedemikian rupa, sehingga seorang mahasiswa siap menjadi wirausaha. Salah satu sifat wirausaha yang paling mendasar, yaitu sifat kreatif dan inovatif, serta kemampuan memanfaatkan peluang dan memecahkan masalah. Oleh sebab itu, pemaham-an dan penguasaan metode untuk mengembangkan kreativitas merupakan dasar seluruh perkuliahan kewirausahaan. Dalam membangun mental kreatif dan inovatif, maka perubahan mindset terhadap diri mahasiswa menjadi sangat penting untuk dilakukan. Mindset mahasiswa harus diubah menjadi mindset seorang entrepreneur, yaitu seorang yang harus aktif dan berwawasan luas dalam memandang sesuatu termasuk cara memandang hidup ini.

Pembentukan generasi muda untuk berpikir mencipta (create), merupakan sebuah solusi awal dalam pembentukan generasi yang unggul untuk mengatasi permasalahan ekonomi yang ada di lingkungan masyarakat. Pada generasi muda kini harus banyak ditumbuhkan wawasan dan pengalaman akan dunia usaha guna menumbuhkan pengusaha asli bangsa atau pengusaha pribumi yang kompeten dan mampu meningkatkan perekonomian bangsa nantinya. Tak terkecuali dalam bidang pendidikan yang dalam hal ini para lulusan dari LPTK harus mampu menjadi Pio- neer pendidikan yang tidak hanya sebatas membantu orang lain mengajar, tetapi juga dapat menghidupi orang lain dengan membuka lembaga pendidikan/ lembaga kursus misalnya. Hal ini perlu dilatih dan dibangun terlebih dahulu mentalitas entrepreneurshipnya, setelah mentalitas itu tumbuh maka langkah selanjutnya barulah melakukan aksi nyata.

Jurusan Manajemen Pendidikan (MP) merupakan salah satu jurusan yang mengajarkan pendidikan kewirausahaan dengan tujuan memberikan bekal kepada mahasiswa agar dapat membangun jiwa kreatif dan inovatif dalam mengelola suatu usaha, khususnya mengelola lembaga pendidikan agar lebih efektif, efisien dan memiliki keunggulan daya saing. Untuk menjadikan mahasiwa jurusan MP menjadi seorang wirausaha unggulan, tentu tidak bisa dilepaskan juga dari keharusan membangun motivasi berwirausaha yang ada pada diri mereka, sehingga pada akhirnya motivasi tersebut dapat membangun mindset Entrepreneirship pada diri mereka.

\section{Rumusan Masalah}

Berdasarkan hal tersebut di atas, peneliti merasa perlu untuk menganalisis apakah mahasiswa jurusan Manajemen Pendidikan FIP UNJ memiliki motivasi entrepreneurship yang kuat?

\section{Kajian Teori}

Manusia dalam melakukan suatu kegiatan, dipengaruhi oleh daya dorong yang timbul dalam dirinya yang disebut motif internal, serta dapat pula dipengaruhi oleh daya dorong yang ditimbulkan oleh lingkungan yang disebut motif eksternal. Motivasi yang dapat menimbulkan harapan akan pemenuhan kebutuhan atau kepuasan disebut motivasi positif. Sedangkan motivasi yang bersifat menimbulkan rasa takut dan cemas disebut motivasi negatif. Kedua motivasi tersebut selalu berkaitan dan tidak pernah berdiri sendiri.

Mitchell mendefinisikan motivasi "motivation as the degree to which an individual wants and chooses to engage in certain specified behavior". Motivasi sebagai tingkat keinginan dan pilihan seseorang untuk melaksanakan perilaku tertentu. Seseorang yang tidak memiliki keinginan tidak akan terdorong untuk melakukan tindakan. Untuk itu seseorang yang memiliki motivasi adalah mereka yang memiliki keinginan sehingga ia berusaha melakukan kegiatan untuk memenuhi keinginannya.

Pemaparan yang hampir sama dikemukakan pula oleh Werther \& Davis (1996) yang mendefinisikan "motivation is a person's drive to take an action because that person wants to do so people act because they feel that they have to". Motivasi merupakan dorongan seseorang 
untuk bertindak karena orang itu ingin melakukannya. Orang bertindak karena mereka merasa bahwa mereka harus melakukan itu.

Kewirausahaan menurut Schumpeter dalam Alma (2009), Entrepreneur as the person who destroys the existing economic order by introducing new products and services, by creating new forms of organization, or by exploiting new raw materials. Dari definisi tersebut dapat dikatakan bahwa wirausaha adalah orang yang mendobrak sistem ekonomi yang ada dengan memperkenalkan barang dan jasa yang baru, dengan menciptakan bentuk organisasi baru atau mengolah bahan baku baru. Selain itu, Lupiyoadi (2004) mendefinisikan, bahwa wirausaha sebagai pelaku utama dalam pembangunan ekonomi dan fungsinya adalah untuk melakukan inovasi, atau menciptakan kombinasi-kombinasi baru.

Jurusan Manajemen Pendidikan merupakan salah satu jurusan yang memasukkan kurikulum entrepreneurship sebagai mata kuliah yang berbobot 2 SKS. Mata kuliah ini dimasukkan dalam kurikulum jurusan dengan tujuan memberikan bekal kepada mahasiswa agar dapat membangun jiwa kreatif dan inovatif dalam mengelola suatu usaha khususnya mengelola lembaga pendidikan agar lebih efektif, efisien, dan memiliki keunggulan daya saing. Dengan diadakannya mata kuliah tersebut, diharapkan mahasiswa dapat memiliki utama dalam melakukan tindakan nyata di lapangan di samping kemampuan berpikir ke depan untuk berusaha mandiri. Kemampuan ini dapat digunakan sebagai bekal nantinya setelah lulus sarjana dan mendapatkan pilihan lebih, dengan menjadi pekerja, wirausahawan, atau menjadi pekerja dan wirausahawan.

A. Peluang dan Tantangan Kewirausahaan dalam Dunia Pendidikan

Pembentukan jiwa entrepreneurship, ialah jiwa keberanian dan kemauan menghadapi problema hidup dan kehidup-an secara wajar, jiwa kreatif untuk mencari solusi dan mengatasi problema tersebut, jiwa mandiri dan tidak bergantung pada orang lain. Salah satu metode untuk menanamkan semangat, jiwa, dan sikap kewirausahaan adalah dengan metode pendidikan life skill.

Salah satu jiwa entrepreneurship yang perlu dikembangkan melalui pendidikan adalah kecakapan hidup (life skill). Life skill adalah kecakapan yang dimiliki seseorang untuk mau dan berani menghadapi problema hidup dan kehidupan secara wajar tanpa merasa tertekan, kemudian secara proaktif dan kreatif mencari serta menemukan solusi sehingga akhirnya mampu mengatasinya.
Dalam banyak kegiatan pembinaan kewirausahaan, tumbuh pemikiran baru untuk mengembangkan daya sekolah dalam membangun berkoperasi, beternak, berdagang, mengembangkan jasa pelayanan publik atau kegiatan produktif. Sementara itu, banyak yang melupakan bahwa kegiatan kewirausahaan juga dapat diperluas maknanya. Bagaimana sekolah menghasilkan perilaku yang memiliki karakter yang kreatif, inovatif, dan pantang menyerah, sehingga berdampak pada pembentukan pribadi yang dinamis yang siap menyambut masa depan yang serba berubah.

Tantangan utama kewirausahaan dalam dunia pendidikan adalah pola pikir kita yang menghalangi kemajuan entrepreneurship di Indonesia. Para generasi muda, memiliki pola pikir bahwa mereka belajar di sekolah untuk akhirnya menjadi pencari kerja daripada pencipta kerja. Sebenarnya hal ini merupakan bagian tidak terpisahkan dari sistem pendidikan nasional kita.

Hal ini didukung dengan nilai budaya dalam sebagian besar anggota masyarakat kita, bahwa menjadi seorang entrepreneur tidak sebaik menjadi pegawai terutama pegawai negeri. Sebagai contoh, dalam sebagian besar masyarakat Jawa, status paling terhormat diberikan kepada keluarga kerajaan, yang berikutnya ialah "Amtenar" yaitu pegawai negeri, dan yang terendah, ialah para pengusaha dan pedagang. Keluhan ini juga dijumpai di kalangan mahasiswa. Mereka mengeluh karena mereka tidak direstui dan didukung oleh orang tua jika mereka ingin menjadi seorang entrepreneur. Menjadi seorang entrepreneur bisa menjadi sebuah aib bagi keluarga.

\section{Membangun Jiwa Kewirausahaan}

Membangun jiwa kewirausahaan haruslah dimulai dengan kemauan kreatif dan inovatif seseorang untuk mencapai suatu tujuan dalam hidupnya. Banyak orang yang berhasil dan sukses karena memiliki kemampuan berfikir kreatif dan inovatif. Hal tersebut penting untuk dipahami mengingat selama ini dalam kehidupan sehari-hari, masih banyak orang yang menafsirkan dan memandang bahwa kewirausahaan identik dengan apa yang dimiliki dan dilakukan oleh "wirausaha" atau "wiraswasta". Untuk mendorong berkembangnya jiwa kewirausahaan, maka menurut Suyana seseorang haruslah memiliki kompetensi. Kompetensi tersebut merupakan syarat utama bagi seseorang yang ingin melakukan proses perjalanan kreativitas berfikir dan inovasi tentang keinginan yang diharapkannya. Wirausaha tidak hanya memerlukan pengetahuan tapi juga keterampilan, diantaranya keterampilan (1) manajerial; (2) konseptual; (3) memahami, mengerti, berkomunikasi, dan berelasi; (4) 
merumuskan masalah dan mengambil keputusan; serta (5) mengatur dan menggunakan waktu.

\section{Teknik Membangun Kepribadian Entrepreneur}

Secara garis besar, teknik membangun kepribadian yang sehat dalam diri adalah dengan meningkatkan kedewasaannya dalam mengaktualisasikan sikap dan perilaku yang dapat diterima oleh orang lain dilihat dari sisi rohani, sosial, emosional, dan intelektual yang bersumber dari kepercayaan diri. Adapun teknik membangun kepribadian wirausaha, maka seseorang harus :

1. Menyadari: arti sukses, nilai potensi diri, nilai potensi orang lain, dan nilai waktu. Kepribadian yang sukses adalah akibat dari sebab-sebab yang kita lakukan. Tidak ada sukses tanpa tindakantindakan tertentu yang mengawalinya.

2. Menginginkan: keinginan yang terumuskan secara jelas dalam bentuk target-target yang cukup berharga untuk diperjuangkan, maka akan mampu menggerakkan kita menuju hasil akhir sukses.

3. Memperjuangkan: lima unsur kepribadian yang harus diperjuangkan, yaitu antusiasme (semangat dan motivasi), komitmen, tindakan nyata, ulet, tidak mudah putus asa, dan doa.

Dengan demikian, seseorang dapat memfokuskan atau mengarahkan pikirannya dalam suatu situasi sebagai peluang ataupun sebagai hambatan seperti halnya hari yang mendung dapat terasa indah, dapat pula terasa buruk. Oleh karena itu, yang dapat menentukan suatu persepsi sebagai suatu proses memandang atau menafsirkan lingkungan seseorang adalah diri sendiri.

E. Faktor Yang Mempengaruhi Kepribadian Entrepreneur

Ada beberapa faktor yang mempengaruhi kepribadian enterpreneur terdasap seseorang, yaitu Perta$m a$, faktor pendidikan yang terkait dengan formal dan informal sangat mempengaruhi usaha-usaha yang bersangkutan untuk meningkatkan tingkat kedewasaan intelektual, di mana seseorang memiliki kemampuan untuk membangun satu kebiasaan efektif, sehingga ia berkesempatan meningkatkan kecakapan-kecakapan yang dibutuhkan dalam mengikuti perubahan.

Kedua, faktor kelamin. Sebagai manusia yang diciptahan Tuhan menjadikan laki-laki dan perempuan sesuai dengan kodratnya, tetapi mereka bisa berperan saling melengkapi. Jadi, bila seorang laki-laki akan berusaha untuk mengembangkan tingkah laku yang sopan, begitu pula perempuan.

Ketiga, faktor keluarga. Dalam hal ini banyaklah pengaruh dari keturunan sebagai pembawaan dari turun temuran sebagai proses biologis dalam mengenai ciri-ciri orang tua yang diteruskan kepada keturunannya.

Keempat, faktor kepercayaan. Memainkan peranan yang besar mempengaruhi usaha-usaha pengembangan kepribadian karena sebagai manusia yang diciptakan Tuhan, seseorang percaya dan memiliki keyakinan, sehingga seseorang memiliki keimanan dan agama yang dianutnya. Dengan kepercayaan itu, memotivasi kekuatan sikap dan perilaku.

Kelima, faktor masyarakat sangat mempengaruhi cara berpikir, bersikap, berperilaku, bahkan juga menumbuhkan nilai-nilai yang kadang kala bertentangan dalam hidup ini. Oleh karena itu, setiap masyarakat mempunyai pandangan sendiri-sendiri mengenai kepribadian manakah yang baik dan patut dihargai. Dalam masyarakat, orang biasanya mengagumi pria dan wanita yang dapat mengendalikan perasaan, bermoral teguh dapat menyesuaikan diri dapat bergaul dan ingin memperbaiki dirinya.

Dengan memahami faktor-faktor yang mempengaruhi pengembangan keperibadian tersebut, maka seseorang mampu berpikir bagaimana sebaiknya memenuhi keperluan dalam perjalanan hidupnya. Pengertian keperluan disini adalah tuntut-an kodrat kita sebagai manusia yang harus dipenuhi secara benar dan tepat agar dapat meraih keberhasilan dan bahagia.

\section{METODE PENELITIAN}

\section{Jenis Penelitian}

Pendekatan yang digunakan dalam penelitian ini adalah pendekatan survei dan analisa data sekunder dengan metode eksploratif dan deskriptif.

\section{Waktu dan Tempat Penelitian}

Penelitian ini dilakukan di Jurusan Manajemen Pendidikan (MP) Universitas Negeri Jakarta dibutuhkan waktu penelitian ini selama 7 bulan, yakni bulan Mei sampai dengan November 2012.

\section{Prosedur Penelitian}

a. Sumber Data

Penelitian yang dilakukan di Fakultas Ilmu Pendidikan Universitas Negeri Jakarta ini melibatkan 3 (tiga) angkatan jurusan Manajemen Pendidikan UNJ yaitu, angkatan 2009, 2010, dan 2011. Adapun jumlah mahasiswa yang dimiliki oleh Manajemen Pendidikan Fakultas Ilmu Pendidikan UNJ yaitu sebanyak 212 mahasiswa terlihat pada tabel 1 .

Tabel 1. Jumlah Mahasiswa Manajemen Pendidikan Tahun 2009-2011

\begin{tabular}{|l|c|}
\hline \multicolumn{1}{|c|}{ Angkatan } & Jumlah Mahasiswa \\
\hline 2009 Reguler & 28 \\
\hline 2009 Non Reguler & 36 \\
\hline
\end{tabular}




\begin{tabular}{|c|c|}
\hline Angkatan & Jumlah Mahasiswa \\
\hline 2010 Reguler & 26 \\
\hline 2010 Non Reguler & 34 \\
\hline 2011 Reguler & 40 \\
\hline 2011 Non Reguler & 48 \\
\hline TOTAL & 212 \\
\hline
\end{tabular}

\section{b. Teknik Pengumpulan Data}

Pengumpulan data dilakukan dengan menggunakan angket. Selain itu, untuk mendukung keabsahan data, maka ditunjang dengan intervieu/wawancara. c. Teknik Analisis Data

Teknik analisis data yang digunakan dalam penelitian ini adalah deskriptif kualitatif.

\section{HASIL DAN PEMBAHASAN}

\section{Temuan Penelitian}

Penelitian ini mengungkap tentang pengembangan jiwa kewirausahaan mahasiswa Manajemen Pendidikan UNJ meliputi: kesiapan setelah lulus strata satu, rencana wirausaha, jenis wirausaha, tantangan dan kendala, pemecahan tantangan dan kendala, upaya mengatasi kendala yang ada, serta manfaat mata kuliah wirausahaan.

a. Aktivitas yang dilakukan setelah menyelesaikan pendidikan

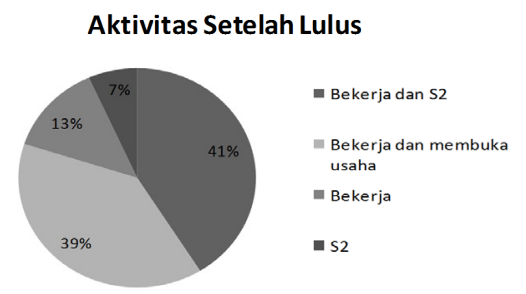

Gambar 1. Aktivitas Mahasiswa Setelah Lulus

Dari gambar 1 terlihat bahwa untuk aktivitas yang akan mereka lakukan setelah menyelesaikan pendidikan sebanyak $41 \%$ responden menjawab ingin bekerja dan melanjutkan strata dua. Sebanyak 39\% responden berminat bekerja untuk mengumpulkan modal setelah modal terkumpul akan digunakan untuk membuka usaha. Selanjutnya sebanyak 13\% menjawab ingin bekerja dan hanya $7 \%$ responden saja yang menjawab ingin melanjutkan S2.

b. Rencana menekuni usaha

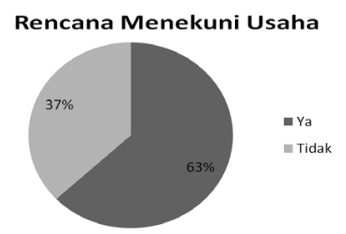

Gambar 2. Rencana Menekuni Usaha

Dari gambar 2 dapat terlihat bahwa pertanyaan terkait keinginan menekuni usaha, sebanyak 63\% responden cenderung menjawab akan berencana menekuni sebuah usaha dengan anggapan bahwa dengan berwirausaha dapat membuka lapangan pekerjaan bagi sesama. Sebanyak 37\% yang menjawab tidak.

c. Jenis usaha yang akan ditekuni

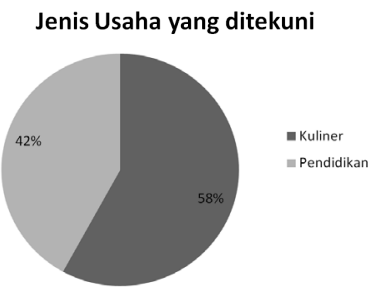

\section{Gambar 3. Jenis Usaha yang Ditekuni}

Pertanyaan terkait jenis usaha yang akan ditekuni, sebanyak $58 \%$ responden cenderung memilih untuk membuka usaha bidang kuliner dengan alasan setiap manusia yang hidup membutuhkan makan dan minum. Selain itu, sebanyak $42 \%$ responden juga memiliki cukup minat untuk berwirausaha di bidang pendidikan, dengan alasan bervariasi. Salah satunya adalah untuk mengimplementasikan ilmu yang dimiliki dalam manajemen pendidikan.

d. Tantangan dan kendala yang dikhawatikan untuk menjadi seorang entrepreneur

Sebanyak $87 \%$ responden mengkhawatirkan sisi pendanaan atau modal yang minim dengan gambaran usaha yang cukup besar. Selain itu, kendala lain yang dikhawatirkan adalah pesaing yang sudah professional, pesaing telah lebih dulu menjalankan usaha. Telah memiliki banyak pengalaman dan kiatkiat dalam memecahkan masalah usaha yang akan dihadapinya, dijawab oleh $13 \%$ responden. Secara rinci dapat dilihat pada gambar 4 .

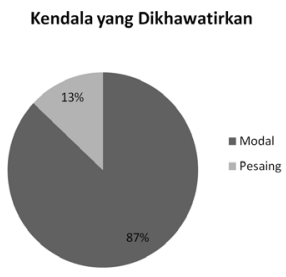

Gambar 4. Kendala yang Dikhawatirkan

e. Upaya entrepreneur untuk mengatasi kendalakendala yang ada.

Berdasarkan permasalahan yang ada, solusinya yaitu mencari sumber dana yang dibutuhkan, baik dengan mencari investor, meminjam kepada bank, dan lain-lain dijawab oleh $63 \%$ responden. Pada aspek pesaing sebanyak $37 \%$ responden menjawab harus tetap optimis dan membuat inovasi-inovasi berbeda dari pesaing yang ada. Secara rinci dapat dilihat pada gambar 5. 


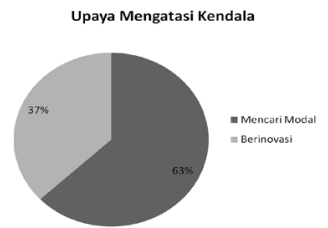

Gambar 5. Upaya Mengatasi Kendala

f. Kebermanfaatan mata kuliah Pendidikan Kewirausahaan dalam menginspirasi untuk berwirausaha

Sebanyak 94\% responden menjawab yakni dengan merubah paradigma mengenai wirausaha. Selanjutnya sebanyak $6 \%$ menjawab mata kuliah pendidikan kewirausahaan dapat menginspirasi untuk menjadi entrepreneur. Secara rinci dapat dilihat pada gambar 6 .

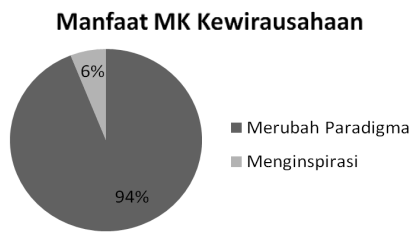

Gambar 6. Manfaat Mata Kuliah Kewirausahaan

\section{Pembahasan}

Aktivitas yang akan dilakukan mahasiswa setelah menyelesaikan studi amat beragam, tetapi mayoritas jawaban responden masih berorientasi untuk bekerja. Bekerja mereka lakukan sebagai batu loncatan untuk membuka usaha dan untuk melanjutkan pendidikan S2. Ada pula yang menjawab ingin bekerja saja atau langsung berwirausaha. akan tetapi ini hanya sebagian kecil saja, tidak lebih dari 10\%. Dari jawaban responden, dapat dilihat bahwa mindset mereka setelah menyelesaikan pendidikan masih berorientasi untuk bekerja. Responden kurang berani untuk mengambil resiko memulai sebuah usaha dengan kendala-kendala yang nantinya akan dihadapi. Dengan bekerja, mereka akan mendapatkan penghasilan tetap dan kontinuitas tidak seperti berwirausaha yang mendapatkan penghasilan dari hasil penjualan yang bergantung kepada pelanggan dan kebutuhan pasar. Hal tersebut menjadi pilihan yang lumrah bagi setiap orang dengan alasan penghasilan tetap dan jam kerja terjadwal. Bagi yang menjawab ingin membuka usaha merupakan tindakan yang sangat berani, yang perlu diapresiasi adalah mental mau mencoba, mau bekerja keras, berani gagal dan mau memulai.

Ketika ditanyakan lebih lanjut keinginan mereka untuk berwirausaha, ternyata $63 \%$ responden menjawab ingin berwirausaha dengan anggapan bahwa dengan berwirausaha dapat membuka lapangan pekerjaan bagi sesama. Berwirausaha juga merupakan sebuah investasi jangka panjang. Bukan hanya sekedar investasi, melainkan penambah penghasilan, karena bekerja saja tidak mencukupi terlebih di zaman ini yang semakin hari biaya untuk memenuhi kebutuhan semakin meningkat. Selain itu, menjadi seorang wirausaha merupakan jalan keluar karena susahnya mencari pekerjaan di kota-kota besar. Ini menandakan bahwa pada dasarnya setiap orang ingin berwirausaha, hanya saja mereka takut untuk memulainya. Sebaiknya ini menjadi pilihan utama mereka, mengingat saat ini lapangan kerja semakin terbatas. Upaya yang diperlukan setelah motivasi itu adalah keberanian untuk memulainya tentunya dengan perencanaan yang matang.

Pertanyaan terkait jenis usaha yang akan ditekuni sebanyak 58\% responden cenderung memilih untuk membuka usaha bidang kuliner dan sisanya menjawab ingin berwirausaha di bidang pendidikan. Mayoritas responden menjawab ingin berwirausaha di bidang kuliner dapat dimaklumi, mengingat orang Indonesia sangat menyukai kuliner. Ini merupakan peluang yang perlu dimanfaatkan, meskipun latar belakang mereka di bidang pendidikan. Selanjutnya, yang berminat berwirausaha di bidang pendidikan juga cukup banyak. Ini sesuai dengan latar belakang pendidikan mereka. Ada yang berminat membuka lembaga kursus, TK, dan sekolah.

Kendala yang khawatirkan untuk menjadi seorang entrepreneur, sebanyak $87 \%$ responden mengkhawatirkan sisi pendanaan atau modal yang minim dengan gambaran usaha yang cukup besar. Sebanyak $13 \%$ responden mengkhawatirkan pesaing yang telah lebih dulu menjalankan usaha, serta telah memiliki banyak pengalaman dan kiat-kiat dalam memecahkan masalah usaha yang akan dihadapinya. Memang modal penting untuk memulai usaha, tetapi sebenarnya modal utama untuk menjadi entrepreneur adalah keberanian dan tekad yang kuat. Sedangkan pesaing dijadikan sebagai motivasi untuk berinovasi yang lebih baik lagi. Kita harus tetap optimis dan membuat inovasi-inovasi berbeda dari pesaing yang ada, dimulai dengan memberikan pelayanan prima kepada pelanggan, bersikap ramah, cepat dan tepat, jeli membaca situasi dan kondisi pasar, membangun jaringan, berani mencoba, bekerja cerdas, dan lain sebagainya.

Mata kuliah pendidikan kewirausahaan yang diajarkan hampir 100\% membantu mengubah paradigma mengenai wirausaha, bahwa dengan berwirausaha dapat membuka pekerjaan bagi banyak orang dan menutup pintu-pintu pengangguran, memberikan motivasi untuk membuka usaha kecil-kecilan, serta memberi gambaran dengan berwirausaha dapat 
menjadi pengusaha muda yang berhasil. Mata kuliah tersebut membekali mahasiswa untuk menumbuhkan jiwa-jiwa entrepreneurship.

\section{PENUTUP}

\section{Kesimpulan}

Dari hasil penelitian yang dilakukan, dapat ditarik beberapa kesimpulan. Pertama, minat mahasiswa jurusan manajemen pendidikan untuk berwirausaha sudah cukup tinggi, akan tetapi masih kurang berani untuk mengambil resiko dengan tantangan yang ada, kurang berani mengimplementasikan usaha yang ada ke dalam realitas.

Kedua, terdapat beberapa permasalahan dalam mewujudkan suatu usaha yang akan dijalankannya, yaitu: (1) Modal, permasalahan modal dikarenakan baru lulus perguruan tinggi dan memiliki modal yang memadai untuk membuka usaha sesuai yang diharapkan. Selain itu, para responden belum berani mengambil resiko untuk menjalankan usahanya, dengan kata lain masih ragu usaha yang akan dilaksanakan; dan (2) Pesaing, permasalahan pesaing dikarenakan belum memiliki inovasi yang lebih menarik, kreatif, unik, dan lebih efisien serta lebih terjangkau dibandingkan pesaing yang sudah ada. Para pelanggan akan melihat sebuah usaha dari aspek tersebut yang harus dimiki oleh para calon entrepreneur.

Ketiga, mata kuliah kewirausahaan menurut para responden telah cukup menginspirasi dan memotivasi untuk menjadi seorang entrepreneur. Selain itu juga, dapat merubah paradigma untuk menjadi wirausahawan karena dengan menjadi wirausahawan akan membuka lapangan pekerjaan dan mengurangi angka pengangguran terdidik.

\section{Saran}

Berdasarkan kesimpulan di atas, terdapat beberapa saran yang dapat diberikan antara lain: Pertama, pihak Fakultas diharapkan dapat mengembangkan program kreativitas mahasiswa bidang kewirausahaan melalui pemberian dana untuk mahasiswa yang memiliki usaha dengan originalitas, kreatifitas, dan ketekunan untuk mengimplementasikan usaha yang diusungnya. Kedua, pihak jurusan diharapkan dapat memberikan pelatihan kewirausahaan dengan narasumber yang mengerti dengan kebutuhan pasar, berpengalaman, dan telah memiliki usaha yang berkembang pesat. Selain itu, memberikan fasilitas berupa buku-buka bacaan terkait kewirausahaan bagi mahasiswa sebagai pengembang pengetahuan terkait wirausaha. Ketiga, para dosen dapat membimbing, memotivasi, memberikan masukan-masukan positif, serta mewadahi dan mengembangkan segala gagasan para mahasiswa yang memiliki bakat dan minat, khususnya bidang wirausaha hingga terwujudnya usaha yang di tekuninya. Keempat, para mahasiswa diharapkan tidak pantang menyerah, tidak mudah putus asa, harus memberikan sebuah inovasi yang bermutu dan terjangkau dalam memulai usaha. Selain itu, dengan semangat pemuda diharapkan mahasiswa mampu membuat terobosan baru yang lebih kreatif dan inovatif agar mampu bersaing dengan pasar lokal hingga pasar global. Dengan meningkatnya semangat wirausaha Indonesia, akan menambah pemasukan negara dan dapat membantu perekonomian masyarakat. Diharapkan nantinya di Indonesia, para pengusaha sudah banyak yang berwajah pribumi yang dapat memanfaatkan segala macam sumber daya negara oleh rakyat dan untuk rakyat sepenuhnya.

\section{DAFTAR PUSTAKA}

Alma, B. (2009). Kewirausahaan untuk mahasiswa dan umum. Bandung: Alfabeta.

Lupiyoadi, R. (2004). Entrepreneurship from mindset to strategy. Depok: Penerbitan Fakultas Ekonomi Universitas Indonesia.

McClelland, D.C., et al. (1976). The achievement motive. New York: John Wiley and Sons.

Rustandi, C. (2012). Pendidikan wirausaha dan kewirausahaan di sekolah. Diakses dari situs http:/ / pendekarinternetmarketing.com/pendidikanwirausaha-dan-kewirausahaan-di-sekolah/ pada tanggal 1 Juni 2012.

Werther, W B., \& Davis, K. (1996). Human resources and personnel management. New York: McGraw Hill. 